\title{
Verification of Numeric Solution by Experiment for Examination Vertical Oscillation of a Mechanical System
}

Martin Svoboda, Josef Soukup

Faculty of production technology and management of Jan Evangelista Purkyně University in Ústí nad Labem, Na Okraji 1001, Czech Republic. E-mail: svoboda@fvtm.ujep.cz

The paper dealt with the influence of geometric asymmetry on the vertical vibration of symmetrically or asymmetrically loaded mechanical system. The system is composed of rigid flexibly linked elements. Kinematic excitation was carried out by a unit jump (jump of the springs), excitation of system was symmetric and asymmetric. The system of elements was examined experimentally and numerically. The numerical model was verified by experimental solution. Numerical solutions were carried out by finite element method (FEM) applied to model that respected the design and conditions of the laboratory model for experimental investigations. The aim of the work was to create a numerical model based on the finite element method and to verify the results of the model. The obtained results can be applied to flexible storage machines.

Keywords: mechanical system, oscillation, unbalance, excitation

\section{Acknowledgement}

This article was supported by Student Grant Competition of J. E. Purkyně University in Ústí nad Labem.

\section{References}

[1] FREIBAUER, L., RUS, L., ZAHRÁDKA, J.: Dynamika kolejových vozidel. Nadas, Praha 1988

[2] CHALUPA M.: Combined Metod of Driving System Dynamic Properties Analysis. In magazine "Machinebuilding \& Electrotechnic". Sofia 2005, ISNN 0025-455X

[3] CHALUPA M., KRATOCHVÍL C. A KOL.: Computer Metod of Analysis of Driving System Dynamic Properties. IN: "AT \& P JURNAL PLUS". Bratislava: HMH S.R.O. Tavarikova Osada 39, 84102 Bratislava 42, 2007, ISNN $1336-5010$

[4] HARUŠINEC J., GERLICI J., LACK T.. Výpočet kontaktního napätia medzi železničním kolesom a kol'ajnicou ротосои MKP, In: Výpočtové a experimentální metody v aplikované mechanice, p. 107-118, Ústí nad labem, 2012, ISBN 978-80-7414-377-9

[5] STEJSKAL, V., OKROUHLÍK, M., Kmitání s matlabem, Vydavatelství ČVUT, Praha, 2002, ISBN 80-01-024350

[6] SOUKUP J., VOLEK J. A KOL., Kmitání mechanických soustav - vozidel, Ústí nad Labem, 2008

[7] WEINFURTNER L., PEXA M., MAYER K.: Stanovení životnosti ložisek na vibrodiagnostickém modelu, In: Strojírenská technologie, p. 52-59, Ústí nad Labem, 2011, ISSN 1211-4162

[8] VRKOSLAVOVÁ L., KRACÍK V.: Aplikace statistické metody ke zpracování naměřených dat, In: Strojírenská technologie, p. 48-52, Ústí nad Labem, 2011, ISSN 1211-4162

[9] NOVÁK P., MEŠKO J., ŽMINDÁK M.: Finite Element Implementation of Multi-Pass Fillet Weld with Phase Changes, In: Manufacturing Technology, Volume 13, p. 79-85, Ústí nad Labem, 2013, ISSN 1213-2489

[10] KOVANDA K., HOLUB L., KOLAŘÍK L., KOLAŘÍKOVÁ M., VONDROUŠ M.: Experimental Verification of FEM Simulation of GMAW Bead on Plate Welding., In: Manufacturing Technology, Volume 12, p. 30-33, Ústí nad Labem, 2012, ISSN 1213-2489 